\title{
Assessment and management of scalds and burns in children
}

\section{Eleanor Hollywood and Tracey O'Neill explain why it is important for nurses involved} in the care of such traumas to have good knowledge of the pathophysiology of this type of injury and the associated physical and psychological consequences

\begin{abstract}
In childhood, burn or scald injuries are comparatively common, and the greatest risk is to infants and toddlers. The extent and severity of injuries can vary greatly, which can significantly affect recovery and outcome. To provide high quality nursing care to the child who has sustained a burn injury and the family, the children's nurse should understand the pathophysiology of the trauma and the associated physical and psychological suffering. Evidence-based nursing management of these aspects is an essential component of recovery. Children's nurses working in hospitals, schools or in the community can engage with parents, families, school staff and children to provide information, advice, and health and safety promotion for burn prevention.
\end{abstract}

Keywords

Accidents and emergencies, accident prevention, burns, children: accidents, child nursing care, first aid

\section{Correspondence}

eleanor.hollywood@tcd.ie

Eleanor Hollywood is assistant professor of children's nursing

Tracey 0 'Neill is nurse tutor, school of nursing and midwifery

Both at Trinity College Dublin, Ireland

Date of submission

May 12013

Date of acceptance

July 72013

Peer review

This article has been subject to open peer review and checked using antiplagiarism software

Author guidelines

ncyp.rcnpublishing.com
BURNS ARE some of the most devastating injuries that can be sustained by the human body. Such traumas occur when there is skin contact with hot liquid, hot surfaces/objects, chemicals, radiation or electricity (Yates et al 2011); skin damage can also result from cold and friction injuries.

Scalds are the most common burn injury seen among children in the UK (Egro et al 2010, Warner et al 2012) and Ireland (Dempsey and Orr 2005, Yates et al 2011). A splash scald is non-uniform in shape and distribution, and has a mixed depth; an immersion scald is more uniform in appearance and usually there are no splash marks. Figure 1 shows examples of scald and burn injuries.

Global studies demonstrate that children aged 0-4 four years have the highest incidence of burn injuries (Rayner and Prentice 2011). A toddler can sustain a severe scald from something as simple as an unattended cup of hot tea, and such trauma can occur in seconds, yet its consequences can have significant physical, emotional and psychological effects on the child's life. Childhood injury prevention is a worldwide concern (Parbhoo et al 2010), but accidental scalds and other burns are largely preventable (Atiyeh et al 2009).

\section{Clinical history}

The nursing care of the child who has sustained a scald or a burn includes making a meticulous record of the details of any injury (Warner et al 2012), incorporating clinical and social history, as well as burn mechanism and thermal agent (Maguire et al 2008). The children's nurse should collate information about the items outlined in Box 1 to obtain a comprehensive record.

\section{Referral}

Criteria for referral to a specialist burns unit vary. However, the British Burns Association (2012) has outlined a minimum threshold for referral of a patient to a specialist burn care service. These criteria for referring a child with burn injuries are listed in Box 2 . During the assessment phase of caring for the child who has sustained a burn, the speedy establishment of a communication link with the nearest specialist burn care service is invaluable to ensure the child receives the most up-to-date evidence-based care and management.

\section{Burn depth}

The depth of burn is crucial, because it will determine how the injury is treated. However, many burns vary greatly in depth, so assessment can be difficult. The skin is made up of three distinct layers: the outermost epidermis layer and the dermis layer, which is anchored to the subcutaneous layer. Table 1 (page 30) outlines the classification of burn depth and the affected skin layers. 
Figure 1 Burn and scald injuries
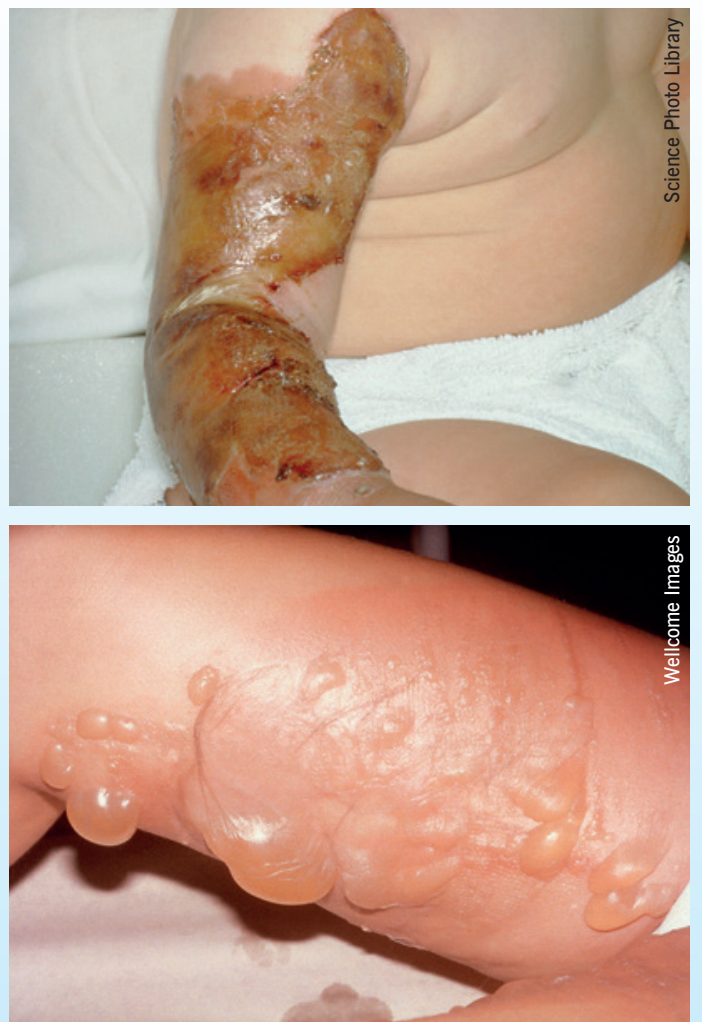

A burn injury (top) and a scald injury (bottom) on the arms of children aged under four years

\section{First aid and assessment}

Adequate first aid following burn injury improves outcome (Graham et al 2012). However, although there are various public health guidelines advising on best first aid treatment, there is a lack of knowledge about this among parents. A UK study by Graham et al (2012) found a significant need to improve parental education and awareness of burns first aid, and a Turkish study by Karaoz (2010) found parental knowledge of appropriate first aid treatment of burns considerably lacking.

The primary objectives of first aid with burns are to (Cuttle and Kimble 2010):

Stop the burning process.

Provide pain relief.

Halt the progression of the burn.

In the UK, prevention of infection is also one of the primary aims.

The use of cold running water for 20 minutes to remove heat energy from the area is recommended as the first-line treatment. Ice must not be used as a cooling measure as it constricts capillaries (McQueen et al 2012).

Subsequent nursing care depends on a number of variables: the child's age, the depth of burn, percentage of total body surface area (TBSA) affected,

\section{Box 1 Information required for detailed history of a child with a scald or burn}

\begin{tabular}{|c|c|}
\hline Clinical & $\begin{array}{l}\text { The child will be initially assessed for airway, breathing } \\
\text { and circulation. } \\
\text { Temperature, heart rate, respiratory rate, blood pressure } \\
\text { and oxygen saturations will be recorded. } \\
\text { Is the burn covered or exposed? } \\
\text { Was any first aid treatment given to the child? } \\
\text { Are there any signs and symptoms of inhalation injury? } \\
\text { Are there any signs of shock? } \\
\text { Does the child appear to be in good condition, with clean } \\
\text { hair, skin and nails? }\end{array}$ \\
\hline Social & $\begin{array}{l}\text { At what time did the child present for treatment? } \\
\text { What age is the child? } \\
\text { Who has brought the child for treatment? } \\
\text { Who does the child live with normally? } \\
\text { Does the child go to school/playschool/crèche? } \\
\text { Has the child been in hospital before? } \\
\text { Has the child received treatment for injury or } \\
\text { illness before? } \\
\text { Has the child reached normal developmental milestones? } \\
\text { Condition on arrival for treatment, for example, crying, } \\
\text { inconsolable, whimpering, or withdrawn. }\end{array}$ \\
\hline Injury & $\begin{array}{l}\text { When did the burn occur (exact time)? } \\
\text { Where was the child at the time? } \\
\text { Who was with the child? } \\
\text { What agent caused the burn to the child? } \\
\text { How exactly did it happen? }\end{array}$ \\
\hline Wound & $\begin{array}{l}\text { Record the site of burn injury. } \\
\text { Using the Lund and Browder chart (child version) } \\
\text { (Bosworth 1997) record the extent of the burn } \\
\text { (percentage of total body surface area). } \\
\text { Describe the distribution of the burn. } \\
\text { Describe the depth of the burn. } \\
\text { Describe the colour of the burn. }\end{array}$ \\
\hline
\end{tabular}

\section{Box 2 Guidelines for referring a child to a specialist} burn care service

Inhalation injury.

All burns $\geq 2 \%$ of total body surface area.

All full-thickness burns.

All circumferential burns.

Any burn not healed in two weeks.

Any burn with suspicion of non-accidental injury.

All burns to the face, hands, feet, perineum or genitalia.

Any chemical or electrical burns.

Any unwell/febrile child with a burn.

- Any concerns about comorbidities that may potentially affect the healing process and outcome.

(Adapted from British Burns Association 2012) 


\begin{tabular}{|l|l|l|l|l|}
\hline Table 1 & Classification of burn depth & & \\
\hline Epidermis & Superficial & $\begin{array}{l}\text { Superficial/ } \\
\text { dermal }\end{array}$ & Deep dermal & Full thickness \\
\hline Dermis & Affected & Affected & Affected \\
\hline $\begin{array}{l}\text { Subcutaneous } \\
\text { layer }\end{array}$ & $\begin{array}{l}\text { Outer part of } \\
\text { dermis affected }\end{array}$ & $\begin{array}{l}\text { Much of the } \\
\text { dermis affected }\end{array}$ & $\begin{array}{l}\text { All of the dermis } \\
\text { affected }\end{array}$ \\
\hline (Fenlon and Nene 2007) & & $\begin{array}{l}\text { Some or all of } \\
\text { the subcutaneous } \\
\text { layer affected }\end{array}$ \\
\hline
\end{tabular}

\section{Table 2 Requirements for maintenance fluids}

\begin{tabular}{|c|c|}
\hline Weight $\mathbf{( k g )}$ & Intravenous fluid \\
\hline $3-10$ & $100 \mathrm{~mL} / \mathrm{kg}$ \\
\hline $11-30$ & plus $50 \mathrm{~mL} / \mathrm{kg}$ for each additional $\mathrm{kg}>10 \mathrm{~kg}$ \\
& plus $20 \mathrm{~mL} / \mathrm{kg}$ for each additional $\mathrm{kg}>30 \mathrm{~kg}$ \\
\hline 30 & \\
\hline (McQueen et al 2012) & \\
\hline
\end{tabular}

location of the burn, and any associated injuries (McQueen et al 2012). The main aspects to address include: fluid resuscitation, nutritional support, pain relief, wound management and psychological care. The core aim of treatment is to restore form, function and feeling to the injured area and promote physical, psychological and emotional recovery (Hettiaratchy and Papini 2004).

\section{Fluid resuscitation}

Children who have sustained burns of greater than 10\% TBSA (excluding erythema) require formal intravenous (IV) fluid resuscitation to prevent burn shock (Fenlon and Nene 2007, Williams 2011). Fluid loss begins immediately after the burn occurs, therefore fluid resuscitation should start from the time of the injury and not from time of admission (McQueen et al 2012). Children have limited physiological reserves; therefore fluid resuscitation must be more precise than for an adult with a similar burn (Sharma and Parashar 2010).

Thermal damage to the skin leads to an increase in capillary permeability, causing a general shift of fluid from the intravascular compartment to the interstitial fluid compartment (Hettiaratchy and Papini 2004), resulting in major fluid loss. As a result, there is a reduction in circulating blood volume, which must be corrected to restore and maintain oxygen delivery to all body tissues that have been damaged by loss of sodium, proteins and water (Williams 2011).

Fluid resuscitation is generally carried out intravenously; therefore adequate IV access must be established as soon as possible (Williams 2011). The most commonly used fluid resuscitation formula in practice is the Parkland Formula (Urdiales-Baker et al 2011), which is:

\section{$4 m L \times$ bodyweight $(\mathrm{kg}) \times \%$ TBSA burned.}

This formula calculates the total fluid required for the first 24 hours of resuscitation, where half is administered in the first eight hours after injury and the remainder over the following 16 hours. Crystalloid fluids are generally used; however, there is continuing debate about using colloids in fluid resuscitation. The decision remains with the treating physician (Urdiales-Baker et al 2011).

The child should also receive hourly maintenance IV fluid in addition to the resuscitation fluid (Hettiaratchy and Papini 2004). Infants are especially at risk of developing hypoglycaemia because of limited glycogen stores; as a result, nursing care should include monitoring glucose levels (Sharma and Pashar 2010). Table 2 outlines how to calculate the amount of fluid required for IV fluid maintenance.

Nursing skills should include care of the child on an IV infusion and the IV site. An IV cannula should be removed if there are signs of infection, phlebitis or infiltration, or if the cannula becomes blocked (Ingram and Lavery 2007). The children's nurse should also maintain an accurate fluid balance record, recording all types of input and output (Green and Huby 2010).

\section{Nutritional support}

Children with burns have significantly increased calorie requirements due to the development of a hypermetabolic state (Sharma and Parashar 2010). This can result in delayed wound healing, organ dysfunction, susceptibility to infection and ultimately death (Saffle and Graves 2007).

Early enteral feeding is essential for the acceleration of healing and prevention of complications however, as feeding by mouth or nasogastric (NG) tube increases, IV fluid support should be reduced (Glasper et al 2010, Khorasani and Mansouri 2010). Some children will be able to eat, but those with $>10 \%$ TBSA burns will require a nutritional assessment by a dietitian as a consequence of their inability to meet their calorie requirements. These children may also need NG tube placement for supplemental enteral feeding (McQueen et al 2012).

Nursing care of the child requiring NG feeding is summarised in Box 3. 


\section{Pain assessment and management}

Every child who sustains a burn will experience pain and distress, irrespective of the cause, depth or size of the burn (Gandhi et al 2010, Butcher and Swales 2012). As the injury heals, the child will experience other forms of discomfort, such as itchiness (Fenlon and Nene 2007).

Pain management and alleviation of discomfort are critical elements in the overall nursing care of a person with a burn. A multidisciplinary child- and family-focused approach should be adopted to combine pharmacological and non-pharmacological pain-relieving interventions (Ratcliff et al 2006, Gandhi et al 2010). To manage pain effectively, children's nurses should be aware of the different types of pain associated with burn injury.

Inadequate pain management can have adverse physiological and emotional effects on the child, so effective pain control is crucial for improving outcome (Gandhi et al 2010). Continuous and accurate assessment of pain is the key to successful treatment (Gandhi et al 2010). However, this can be difficult in infants and children, and the child's age, developmental level, cognitive and communication abilities and previous pain experiences must all be considered. There are various pain assessment tools for children that nurses can use to assess, plan, implement and evaluate appropriate pain management and care.

The most popular methods used to measure pain intensity include self-reporting tools, and behavioural and physiological measures (Srouji et al 2010). Selfreport tools are considered the most valid measure and are suitable for verbal children over the age of four years (Jacob 2011). Behavioural and physiological pain measurement tools consist of assessment of vital signs, crying, facial expressions, body postures and movement, and are used generally for children from infancy to four years of age, where communication is difficult (Srouji et al 2010, Jacob 2011).

\section{Box 3 Primary care aspects for a child requiring nasogastric feeding}

Correct placement of a short-term PVC nasogastric tube.

Check tube placement with $\mathrm{pH}$ indicator paper before each use.

Maintain accurate fluid balance chart.

Follow dietitian's feeding regimen precisely and report child's tolerance.

Stop feed immediately if there are signs of breathing difficulties.

(Clynes and O'Connor 2010)
The Wong-Baker FACES ${ }^{\circledR}$ Pain Rating Scale is a self-reporting tool that combines facial expressions, numbers and words. The children's nurse explains what each face represents and asks the child to choose the face that best describes the pain (Wong and Baker 1988).

The FLACC scale is a behavioural pain assessment tool that consists of five categories:

F Face.

L Legs.

A Activity.

C Cry.

C Consolability.

It provides a simple and consistent method of pain assessment in non-verbal or preverbal children. Each of the five categories is scored between zero and two, and provides a total score of between zero and ten (Merkel et al 1997).

The Itch Man Scale is specific for burns and uses pictures based on children's personal drawings of their itch discomfort. The drawings create a score of the severity of the itch, using a five-point Likert scale to rate intensity (Marvin and Blakeney 2000).

Pharmacological pain relief Pharmacological approaches to pain management are the mainstay of treatment for a child with a burn injury. In the initial resuscitative period, IV opioid analgesia can be administered for pain relief (Sharma and Parashar 2010). Background pain between wound-care procedures can be managed with regular analgesia (Connor-Ballard 2009). Procedural pain, which is more severe than background pain and can be excruciating, requires more intense analgesia pre-procedure (Connor-Ballad 2009, Gandhi et al 2010).

Poorly controlled procedural pain can cause the child to experience anticipatory anxiety, whereby the fear of pain increases before a procedure begins, which goes on to lower the pain threshold and cause hypervigilance (Wiechman-Askay et al 2009). Sedation should not be administered routinely but, if a child is particularly anxious or frightened, this may be necessary (Nilsson and Renning 2012).

\section{Non-pharmacological pain relief Alternative} interventions for pain relief can be effective for treating children's pain if used in combination with analgesia. They include strategies such as covering the burn so air movement cannot irritate the exposed nerve endings and cause further pain (Ball et al 2010). In the UK, other strategies such as breathing exercises and relaxation techniques for children have also been found helpful, and guided imagery, distraction (Jacob 2011) and technologybased preparation (Miller et al 2010) are widely used. 


\section{Table 3 Dressings used for scalds and other burns in children}

\begin{tabular}{l|l|l|l|} 
Dressing & Description & $\begin{array}{l}\text { Frequency of } \\
\text { dressing change }\end{array}$ & Use \\
\hline $\begin{array}{l}\text { Low } \\
\text { adherence } \\
\text { or occlusive }\end{array}$ & $\begin{array}{l}\text { Laid directly on } \\
\text { the wound; allow } \\
\text { exudate to move }\end{array}$ & $\begin{array}{l}\text { Every 5-10 days, } \\
\text { change of secondary } \\
\text { layer as required }\end{array}$ & $\begin{array}{l}\text { Superficial burns with } \\
\text { minimal exudates }\end{array}$ \\
\hline linal
\end{tabular}

dressings through from the

wound bed. Low

adherence, minimal

pain on removal

\begin{tabular}{|c|c|c|c|}
\hline $\begin{array}{l}\text { Foam } \\
\text { dressings }\end{array}$ & $\begin{array}{l}\text { Used as secondary } \\
\text { dressings }\end{array}$ & $\begin{array}{l}\text { Change as needed } \\
\text { depending on the } \\
\text { amount and nature of } \\
\text { exudates }\end{array}$ & $\begin{array}{l}\text { Used for exuding } \\
\text { wounds. Secure in } \\
\text { place with crepe } \\
\text { bandage }\end{array}$ \\
\hline Soft gauze & $\begin{array}{l}100 \% \text { cotton } \\
\text { non-fibre shedding } \\
\text { gauze used over the } \\
\text { occlusive dressings }\end{array}$ & $\begin{array}{l}\text { Change as needed } \\
\text { depending on the } \\
\text { amount and nature of } \\
\text { exudates }\end{array}$ & $\begin{array}{l}\text { Used to absorb, } \\
\text { cushion, protect, and } \\
\text { hold primary dressings } \\
\text { in place. Secure with } \\
\text { tape or bandage }\end{array}$ \\
\hline $\begin{array}{l}\text { Hydrocolloid } \\
\text { dressings }\end{array}$ & $\begin{array}{l}\text { Soak up exudate } \\
\text { and form a gel that } \\
\text { keeps the wound } \\
\text { warm and moist }\end{array}$ & $\begin{array}{l}\text { Up to every } \\
\text { seven days, } \\
\text { depending on } \\
\text { exudates }\end{array}$ & $\begin{array}{l}\text { Partial-thickness } \\
\text { burns }\end{array}$ \\
\hline $\begin{array}{l}\text { Antimicrobial } \\
\text { creams }\end{array}$ & $\begin{array}{l}\text { Used in conjunction } \\
\text { with dressings to } \\
\text { reduce the risk of } \\
\text { bacterial infection of } \\
\text { a wound }\end{array}$ & $\begin{array}{l}\text { Replace every } \\
24 \text { hours or more } \\
\text { frequently if } \\
\text { excessive exudate }\end{array}$ & $\begin{array}{l}\text { For full- or partial- } \\
\text { thickness, hand and } \\
\text { perineal burns, must } \\
\text { use } 3-5 \mathrm{~mm} \text { thickness. }\end{array}$ \\
\hline $\begin{array}{l}\text { Silver } \\
\text { dressings }\end{array}$ & $\begin{array}{l}\text { Layered } \\
\text { nanocrystalline } \\
\text { silver dressings }\end{array}$ & $\begin{array}{l}\text { Change dressing } \\
\text { every three or seven } \\
\text { days or more } \\
\text { frequently if excessive } \\
\text { exudate is present }\end{array}$ & $\begin{array}{l}\text { Used for deep } \\
\text { partial-thickness and } \\
\text { full-thickness burns, } \\
\text { at-risk donor sites and } \\
\text { graft recipient sites }\end{array}$ \\
\hline
\end{tabular}

(O'Sullivan et al 2010, McQueen et al 2012) promote complete wound closure as soon as possible (Sharma and Parashar 2010). Areas for consideration include wound cleansing, debridement and dressing selection, and the children's nurse plays a crucial role in these care aspects (Krishnamoorthy et al 2012).

Cleaning and debridement Nursing care includes cleansing and debridement of the wound using soap and water or mild antibacterial wash

(Alsbjorn et al 2007). This allows for better inspection of the wound surface and removal of necrotic tissue, exudate and application of topical preparations (Krishnamoorthy et al 2012). Debridement is performed using gentle mechanical techniques such as brushing or scraping (Krishnamoorthy et al 2012). However, in children with large, full-thickness burn wounds, early excision of dead tissue should be carried out as soon as the child is stable to prevent complications (Urdiales-Baker et al 2011); this may require anaesthetic cover. Protocols for excision of eschar vary and nurses must adhere to local policies.

Burn blisters form when the epidermis separates from the dermis. This occurs as a physiological response to the injury. There are many theories on the management of burn blisters and many approaches to care, but there is no consensus about the most effective treatment. Edwards (2011) describes the three most common ways of managing burns blisters:

- Leave the blister intact.

- Aspirate fluid from the blister, leaving the devitalised epidermis intact.

Deroof the blister, removing the epidemis.

Which dressing? After debridement and blister management, the wound must be assessed and covered, and children's nurses play an important part in dressing selection and maintenance. However, because of the complexity of burn management, this aspect of care will require an integrated multidisciplinary approach. Selig et al (2012) suggest that the ideal burn wound dressing must meet the following criteria:

- Be non-adhesive.

Be absorbent.

Have antimicrobial properties.

- Be easily removable.

Guarantee pain-free dressing changes.

- Be available in a range of sizes.

The dressing should also provide the right environment to promote healing (Baranoski 2008) and, although a range of dressings and antimicrobial creams is available, there is no consensus on which is the best. The choice, therefore, depends on cost, availability and frequency of dressing changes 
(McQueen et al 2012). Table 3 outlines some of the most commonly used dressings for scalds and other burns in children (O'Sullivan et al 2010, McQueen et al 2012).

\section{Psychological care}

A burn injury is a traumatic experience for a child and the family, and requires long-term individualised psychological and emotional support. The child may exhibit signs of extreme anxiety as a result of the initial trauma, repeated exposure to painful procedures, possible separation from parents/carers during procedures and the effects of long-term hospital stay (McQueen et al 2012). The parents of the child will also require emotional and psychological support as they may experience feelings of shock, guilt and anxiety and undergo temporary disruption of family relationships (Williams 2011).

The children's nurse can use the following pointers to help manage the psychological aspects associated with caring for the child who has sustained a scald or a burn:

Involve family members in care and decision making, as this will enhance recovery and promote empowerment.

Provide clear, concise information for the child, parents and carers to ensure understanding and reduce anxiety.

- Adopt a family-centred approach, as this will alleviate the child's and family' fear and anxiety.

\section{Conclusion}

The children's nurse plays an important role in the hospital care of the child who has sustained a burn, as well as in the education and promotion of burn prevention in childhood. Children's nurses who work in hospitals, schools or in the community are well positioned to engage with parents, families, school staff and children to provide practical advice and health promotion for burn prevention.

\section{Online archive}

For related information, visit our online archive and search using the keywords.

\section{Conflict of interest}

None declared

\section{References}

Alsbjorn B et al (2007) Guidelines for the management of partial thickness burns in a general hospital or community setting: recommendations for a European working party. Burns. 33, 2, 155-160.

Atiyeh BS et al (2009) Burn prevention mechanisms and outcomes: pitfalls, failure and successes. Burns. 35, 2, 181-193.

\section{Ball JW et al (2010) Child Health Nursing:} Partnering with Children and Families. Second edition. Pearson, Upper Saddle River NJ.

Baranoski S (2008) Choosing a wound dressing: part 1. Nursing. 38, 1, 60-61.

Bosworth C (1997) Burns Trauma: Management and Nursing Care. Baillière Tindall, London.

British Burns Association (2012) National Burn Care Referral Guidance. BBA, London.

Butcher M, Swales B (2012) Assessment and management of patients with burns. Nursing Standard. 27, 2, 50-56.

Clynes M, O Connor C (2010) Gastrointestinal system. In Coyne I et al (Eds) Clinical Skills in Children's Nursing. Oxford University Press, Oxford.

Connor-Ballard P (2009) Understanding and managing burn pain: Part 1. American Journal of Nursing. 109, 4, 48-56.

Cuttle L, Kimble RM (2010) First aid treatment of burn injuries. Wound Practice and Research. 18, 1, 6-13.

Dempsey MP, Orr DJA (2005) Are paediatric burns more common in asylum seekers? An analysis of paediatric burn admissions. Burns. 32, 2, 242-245.

Edwards J (2011) Managing wound pain in patients with burns using soft silicone dressings. Wounds UK. 7, 4, 122-126.
Egro F et al (2010) Pediatric superficial scald burns reassessment of our follow-up protocol. Journal of Burn Care and Research. 31, 1, 196-199.

Fenlon S, Nene S (2007) Burns in children. Continuing Education in Anesthesia, Critical Care and Pain. 7, 3, 76-80.

Gandhi M et al (2010) Management of pain in children with burns. International Journal of Pediatrics. doi: 10.1155/2010/825657.

Glasper AG et al (Eds) (2010) Oxford Handbook of Children's and Young Peoples Nursing. Oxford University Press, Oxford.

Graham HE et al (2012) Are parents in the UK equipped to provide adequate burns first aid? Burns. 38, 3, 438-443.

Green M, Huby K (2010) Cardiovascular system. In Coyne I et al (Eds) Clinical Skills in Children's Nursing. Oxford University Press, Oxford.

Hettiaratchy S, Papini R (2004) Initial management of major burns II - assessment and resuscitation. British Medical Journal. $329,7457,101-103$

Ingram P, Lavery I (2007) Periphera intravenous cannulation: safe insertion and removal technique. Nursing Standard. $22,1,44-48$

Jacob E (2011) Pain assessment and management in children. In Hockenberry MJ, Wilson D (Eds) Wong's Nursing Care of Infants and Children. Mosby Elsevier, St Louis MO.

Jolley J, Shields L (2009) The evolution of family-centred care Journal of Pediatric Nursing. 24, 2, 164-170.

Karaoz B (2010) First-aid home treatment of burns among children and some implications at Milas, Turkey. Journal of Emergency Nursing. $36,2,111-114$.
Khorasani EN, Mansouri F (2010) Effect of early enteral nutrition on morbidity and mortality in children with burns. Burns. 36, 7, 1067-1071.

Krishnamoorthy V et al (2012) Pediatric burn injuries. International Journal of Critical Illness and Injury Science. 2, 3, 128-134.

Maguire S et al (2008) A systematic review of the features that indicate intentional scalds in children. Burns. 34, 8, 1072-1081.

Marvin J, Blakeney P (2000) Itch Man Scale. Shriners Hospitals for Children, Tampa FL.

McQueen S et al (Eds) (2012) The Great Ormond Street Hospital Manual of Children's Nursing Practice. Wiley-Blackwell, Oxford. Merkel SI et al (1997) The FLACC: a behavioural scale for scoring postoperative pain in young children. Pediatric Nursing. 23, 3, 293-297.

Miller K et al (2010) A novel technology approach to pain management in children with burns: a prospective randomized controlled trial. Burns. 37, 3, 395-405.

\section{Nilsson S, Renning AC (2012) Pain} management during wound dressings in children. Nursing Standard. 26, 32, 50-55.

O'Sullivan B et al (2010) Hydrocolloid dressing in pediatric burns may decrease operative intervention rates. Journal of Paediatric Surgery. 45, 3, 600-605.

Parbhoo A et al (2010) Burn prevention programs for children in developing countrie require urgent attention: a targeted literature review. Burns. 36, 2, 164-175.

Ratcliff SL $\boldsymbol{e t}$ al (2006) The effectiveness of a pain and anxiety protocol to treat the acute paediatric burn patient. Burns. 32, 5, 554-562

Rayner R, Prentice J (2011) Paediatric burns: a brief global review. Wound Practice and Research. 19, 1, 39-46.
Saffle JR, Graves C (2007) Nutritional support of the burned patient. In Herndon DN (Ed) Total Burn Care. Third edition. Elsevier, Philadelphia PA.

Selig HF et al (2012) The properties of an 'ideal' burn wound dressing - what do we need in daily clinical practice? Results of a worldwide online survey among burn care specialists. Burns. 38, 7, 960-966.

Sharma RK, Parashar A (2010) Special considerations in paediatric burn patients. Indian Journal of Plastic Surgery Supplement. 43, (Suppl), S43-S50.

Srouji R et al (2010) Pain in children: Assessment and nonpharmacological management. International Journal of Pediatrics. doi: 10.1155/2010/474838 Urdiales-Baker RA et al (2011) Conditions that produce fluid and electrolyte imbalance. In Hockenberry MJ, Wilson D (Eds) Wong's Nursing Care of Infants and Children. Mosby Elsevier, St Louis MO.

Warner RM et al (2012) Cooling properties of everyday liquids. Burns. 38, 8, 1186-1191.

Wiechman-Askay S et al (2009) Pain management in patients with burn injuries. International Review of Psychiatry. $21,6,522-530$.

Williams C (2011) Assessment and management of pediatric burn injuries. Nursing Standard. 25, 25, 60-68.

Wong DL, Baker CM (1988) Pain in children: comparison of assessment scales. Pediatric Nursing. 14, 1, 9-17.

Yates J et al (2011) Patterns of scald injuries in children: has anything changed? Irish Medical Journal. 104, 9, 263-265. 
Copyright of Nursing Children \& Young People is the property of RCN Publishing Company and its content may not be copied or emailed to multiple sites or posted to a listserv without the copyright holder's express written permission. However, users may print, download, or email articles for individual use. 